УДК 342.9

DOI https://doi.org/10.32837/pyuv.v0i2(27).200

\author{
О. А. Моргунов \\ кандидат юридичних наук, доцент, \\ завідувач кафедри спеціальної фізичної підготовки \\ Харківського національного університету внутрішніх справ
}

\title{
ФІЗИЧНА КУЛЬТУРА ТА СПОРТ ЯК НАПРЯМ ПУБЛІЧНОГО АДМІНІСТРУВАННЯ В УКРАЇНІ
}

Сфера фізичної культури та спорту являє собою окрему сферу загальної культури, розвиток якої нині визначено одним із провідних напрямів державної політики в України задля вирішення проблем, які склалися зі здоров'ям, способом життя, спортивними досягненнями у всіх видах спорту, вікових категоріях населення України.

Питання напрямів публічного адміністрування вивчалося низкою науковців, серед яких В.Б. Авер'янов, О.М. Алікова, В.А. Базенко, I.M. Мінаєва, О.I. Миколенко, С.В. Нікітенко, O.М. Обозна, В.В. Сімутін, А.О. Селіванов, О.І. Сушинський, Ю.М. Шкребтій та інші, що їх праці стали основою написання цієї статі.

Статистика свідчить про необхідність змін у сферах фізичної культури та спорту, через розвиток яких можна підвищити рівень здоров'я населення, сприяти здоровому способу життя, гідно представляти Україну у спортивних змаганнях, чим не тільки підвищувати спортивні досягнення, але і піднімати як спортивні рейтинги (як рейтинг футбольних збірних світу, де Україна посідає 29 місце), так і рейтинги України за такими базовими показниками, як очікувана тривалість життя, смертність, індекс людського розвитку (Human Development Index) тощо.

Метою цієї статті є визначення напрямів дій суб'єктів публічного адміністрування у сферах фізичної культури та спорту в Україні задля вирішення проблем, які нині актуальні.

Останні 40-50 років у високорозвинутих країнах завдяки державній політиці смертність людей зменшилася на 15\%, збільшилася тривалість життя на 15-20 років. Натомість в Україні ми маємо шокуючі показники здоров'я населення, Україна посідає перше місце за рівнем смертності в Європі. В Україні займаються фізичною культурою і спортом приблизно $13,5 \%$ населення, що набагато менше, ніж у розвинених країнах, де цей показник становить від 40 до 50\% [1, с. 156]. За даними Міністерства охорони здоров'я України, серед учнів загальноосвітніх навчальних закладів спостерігаються функціональні відхилення в діяльності різних систем організму - у $50 \%$, серцево-судинної системи - у $26 \%$, нервово-психічні розлади - у $33 \%$, захворювання органів травлення - у $17 \%$, захворювання ендокринної системи у $10 \%$ школярів. Так, у 2014 р. захворюваність дітей віком від 0 до 17 років в Україні становила 1286,1 випадку на 1000 осіб відповідного віку (у 2013 р. - у 1394,4 випадку). За даними Міністерства освіти і науки України, $36 \%$ учнів загальноосвітніх шкіл мають низький рівень фізичного здоров'я, $34 \%$ - нижче за середній, $22 \%$ - середній, $7 \%$ - вище за середній і лише $1 \%$ - високий. Схожі тенденції спостерігаються і в інших вікових категоріях населення України [2], що потребує вирішення на всіх рівнях управління.

M.С. Калина визначає: «Спорт та фізична культура відіграє значну роль у житті сучасного суспільства на багатьох рівнях: від забезпечення здоров'я нації до формування іміджу держави на міжнародній арені, від соціальної адаптації молоді до сприяння сталому розвитку. Фізична культура та масовий спорт безпосередньо пов'язані із якістю життя усіх вікових груп населення, спорт вищих досягнень - важлива сфера професійного життя, сектор економіки, засіб укріплення міжнародного авторитету держави» [3, с. 91]. I нині на законодавчому рівні перед державою та громадянським суспільством поставлене завдання "визначення провідної ролі фізичної культури і спорту як важливого фактору здорового способу життя, профілактики захворювань, формування гуманістичних цінностей, створення умов для всебічного гармонійного розвитку людини, сприяння досягненню фізичної та духовної досконалості людини, виявлення резервних можливостей організму, формування патріотичних почуттів у громадян та позитивного іміджу держави у світовому співтоваристві» [4]. І це завдання цілком логічно виходить із призначення спорту та наслідків розвитку фізичної культури як самостійної і особливої галузі «загальної культури, яка спрямована головним чином на зміцнення здоров'я людини, продовження її творчої активності та життя, а також на зростання і вдосконалення іï всебічного й гармонійного розвитку і використання набутих якостей у суспільній, трудовій та інших видах діяльності" [5, с. 40]. С.В. Ліщук вважає: «В умовах соціально-економічних і політичних перетворень сучасної України особливого значення набувають питання зміцнення фізичного і духовного здоров'я людини, формування здорового способу життя $<. .>$ Фізична культура є важливим засобом підвищення соціальної та трудової активності лю- 
дей, задоволення їх моральних, естетичних і творчих запитів, життєво важливої потреби взаємного спілкування, розвитку дружніх стосунків між народами» [6].

Водночас, незважаючи на заходи щодо пропаганди та формування здорового способу життя, які вживаються з боку державних і громадських структур, нині в Україні значних позитивних зрушень у покращенні фізичної, духовної, психічної, соціальної складників здоров'я населення не відбувається [5, с. 39-40, 42]. А тому потрібна виважена та обгрунтована стратегія реформування відповідного сектору, неабияку роль у розробленні та впровадженні якої відведено публічному адмініструванню.

Ця роль, як нам видається, проявляється для суб'єктів публічного адміністрування у двох аспектах. По-перше, суб'єкти публічного адміністрування входять до числа розробників державної політики у сфері фізичної культури та спорту. При цьому, аналізуючи роль органів держави, які здійснюють публічне адміністрування вказаної сфери, можна дійти висновку про провідну роль держави в публічному адмініструванні сфер фізичної культури і спорту в Україні. У Конституції України закріплено обов'язок держави дбати про розвиток фізичної культури і спорту (ст. 49[7]). Для цього Мінмолодьспорту України визначене «головним органом у системі центральних органів виконавчої влади, що забезпечує формування та реалізує державну політику у <...> сферах фізичної культури і спорту» (абз. 2 п. 1 Положення про Міністерство молоді та спорту України, затвердженому постановою Кабінету Міністрів України від 2 липня 2014 р. № 220 [8]) і наділене широкими повноваженнями у відповідній сфері: на визначення перспективи та пріоритетних напрямів розвитку сфер фізичної культури і спорту, забезпечення нормативно-правового регулювання цих сфер, погодження проектів законів, інших актів законодавства, які надходять на погодження, координацію заходів з питань розвитку дитячого, дитячо-юнацького спорту, резервного спорту, масового спорту, спорту вищих досягнень, спорту осіб з інвалідністю, спорту ветеранів; встановлення порядку надання, та надання дитячо-юнацьким спортивним школам категорій; заснування в установленому порядку державних центрів олімпійської підготовки тощо (п. 4 вказаного Положення).

Така визначальна роль і позиція центрального органу влади серед суб'єктів публічного адміністрування сфери фізичної культури та спорту в Україні пояснюється історичними передумовами та попереднім розвитком управління в державі загалом, а не тільки цієї сфери. Спадкування системи управління після розпаду СРСР не тільки включає спадковість науки, про яку ми зауважували в попередньому підрозділі, але і спадковість діючої системи управління. Командно-адміністративна система державного управління, визначальна роль держави та централізація управління, державна власність, «замкненість» вітчизняної фізичної культури та інші засади розвитку сфери фізичної культури та спорту, які були основою управління за радянських часів, були основою для становлення та подальшого розвитку сучасного публічного адміністрування в незалежній Україні, передумовами для його особливостей.

До числа таких особливостей зараховуємо «надлишкові» функції центрального органу виконавчої влади, що формує та реалізує політику у сферах фізичної культури та спорту. Наприклад, нині Мінмолодспорту України все ще має повноваження на затвердження правил спортивних змагань із видів спорту, визнаних в Україні (підп. 17 п. 4 Положення про Міністерство молоді та спорту України, затвердженому Постановою Кабінету Міністрів України від 2 липня 2014 р. № 220 [8]). Хоча аналогічні функції здійснюють і міжнародні та національні федерації, а тому в їх дублюванні потреба відсутня. Саме спортивні федерації з різних видів спорту відповідають за спорт вищих досягнень і за участь спортсменів у національних і міжнародних змаганнях. Спортивні федерації з різних видів спорту, будучи громадськими об'єднаннями згідно з організаційно-правовою формою, набули дозвільних функцій стосовно інших суб'єктів суспільних відносин у царині професійного спорту [9, с. 96].

У підп. 36 п. 4 Положення про Міністерство молоді та спорту України, затвердженому Постановою Кабінету Міністрів України від 2 липня 2014 р. № 220 [8], визначене повноваження організовувати та забезпечувати будівництво і реконструкцію спортивних споруд, коли для цього Міністерство не має сил та засобів і залучає третіх осіб. Це ж стосується і виконання функції організації здійснення контролю за якістю фізкультурно-спортивних послуг, що визначена у підп. 39 п. 4 вказаного Положення. У підп. 41 п. 4 визначено повноваження на проведення інформаційно-пропагандистської роботи з питань фізичної культури і спорту, здорового способу життя та національно-патріотичного виховання. Водночас для цього в Мінмолодспорту обмежені ресурси, відсутні власні засоби масової інформації, окрім інтернет-масмедіа. Поряд з означеними проблемами дублювання повноважень суб'єктів публічного адміністрування сфер фізичної культури та спорту та визначної ролі держави у відповідному процесі описані повноваження Мінмолодьспорту України, які не притаманні аналогічним структурам апаратів держав європейських країн, є передумовою корупції у вказаній сфері. За умови недостатньої прозорості в діяльності суб'єктів публічного адміністрування ці проблеми є вкрай актуальними і не можуть 
бути вирішені поодинці, потребуючи комплексності підходу.

Нині залишається нерівномірним розподіл управлінських повноважень серед таких суб'єктів публічного адміністрування, як органи держави та органи місцевого самоврядування. 0.М. Алікова визначає: «Серцевину керування утворює багатобічна організуюча діяльність державних органів керівництва фізичною культурою і спортом» [10, с. 211]. Також наявна залежність об’єктів управління у сферах фізичної культури та спорту від суб'єктів, що особливо проявляється у взаємодії національних спортивних федерації та центрального органу виконавчої влади, який формує та реалізує державну політику у сферах фізичної культури та спорту в Україні. Тим самим порушується рівновага між державною владою та муніципальною владою, між державою і громадянським суспільством у процесі управління сферою фізичної культури та спорту в Україні.

Як вважає С.В. Нікітенко, нині на перший план виходять питання переосмислення ролі та місця держави, а також місцевого самоврядування в розвитку і підвищенні ефективності системи фізичної культури для забезпечення здоров'я нації, ефективності функціонування спорту [9, с. 95]. Вважаємо, що перегляд провідної ролі держави, розподілу функцій між вказаними суб'єктами має бути одним із напрямів реформування публічного адміністрування сфери фізичної культури та спорту. Іншими словами, поряд із першим аспектом у вигляді формування політики держави у сфері фізичної культури органами публічного адміністрування, їх роль у реформуванні вказаної сфери полягає у зміні парадигми управління на основі людиноцентристської теорії [11, с. 54] та досягнення в управлінні паритетності суб'єктів публічного адміністрування. Основна мета реформування, вважає В.А. Базенко, - «узгодження нашої системи з провідними міжнародними стандартами, побудова нових ефективних взаємовідносин між усіма організаціями, задіяними у спортивній галузі, посилення ролі інституту місцевого самоврядування у розвитку фізичної культури та спорту» [12, с. 172].

При цьому акцентуємо на паритетності суб'єктів публічного адміністрування в управлінні сферами фізичної культури та спорту в Україні як запоруки їх розвитку та доступності для всіх. Це означає, що йдеться не про відмову від державного регулювання сфер фізичної культури та спорту, а про чітке визначення форм і методів управління, порядку взаємодії суб'єктів публічного адміністрування на засадах партнерства, паритетності, координації. Ю.М. Шкребтій вважає: «Ні в кого сьогодні не викликає сумніву факт залучення держави в спорт, хоча мотиви цього залучення досить різноманітні і залежать від безлічі факторів. Це і тип держави, її історичні традиції, політичні і соціально-економічні умови, система суспільних і культурних цінностей, демографічні й освітні характеристики, релігія тощо. Причому вплив цих мотивів оцінюється по-різному на окремих етапах розвитку тієї чи іншої держави. Але головною, безсумнівно, є пануюча в цій країні система поглядів, що істотно визначає існуючу в країні модель спорту й організаційну структуру національного спортивного руху» [13, с. 2]. В.А. Базенко найвизначнішим наслідком зміцнення місцевого самоврядування називає те, що «держава загалом краще виконує свої функції. Коли громадяни довіряють своїм посадовцям i більш активно залучаються до покращання стану справ у своїх громадах, їхнє ставлення до держави також змінюється на краще. Таким чином, хоча обсяг повноважень центрального уряду внаслідок децентралізації може звужуватися, легітимність держави загалом зміцнюється. Тому децентралізацію можна розглядати як спосіб, від застосування якого виграють усі рівні влади і громадяни одночасно» [14, с. 62]. Державна політика у сфері фізичної культури та спорту, як вважає М.С. Калина, має важливе значення для розвитку країни та потребує уваги з боку держави та громадянського суспільства, їх плідної взаємодії, адже тільки за таких умов можна досягти створення сприятливого середовища для розвитку цієї сфери з урахуванням інтересів усіх зацікавлених сторін» [3, с. 91].

Підсумовуючи викладене, доходимо висновку про двоаспектну концепцію дій суб'єктів публічного адміністрування в рамках реформування сфер фізичної культури та спорту в Україні, що характеризує роль та значення публічного адміністрування в системі управління відповідними сферами. 3 одного боку, необхідними є зміни державної політики у сферах фізичної культури та спорту у напрямі підвищення рівня обізнаності всіх вікових категорій населення України про важливість занять спортом, сприяння здоровому способу життя, поширення масового спорту, підвищення результативності професійного спорту, для чого суб'єкти публічного адміністрування мають необхідні ресурси та повноваження. 3 іншого боку, дії суб’єктів публічного адміністрування в рамках реформування сфер фізичної культури та спорту в Україні мають охоплювати зміни відповідної системи управління в аспекті розподілу повноважень між суб'єктами публічного адміністрування, принципів, форм, методів їх діяльності, децентралізації публічного адміністрування.

При цьому ми вважаємо, що тільки науково обгрунтовані та послідовні реформи дадуть результати підвищення якості публічного адміністрування сфер фізичної культури та спорту, їх розвитку як дієвих засобів «для виховання всебічно гармонійного розвитку особистості, які по- 
єднують у собі освітню, оздоровчу, виховну та інші ланки» [5, с. 40]. А тому втілення вказаної концепції реформування має включати юридичну зміну принципів, форм і методів управління в законодавстві України, на основі сучасних розробок науки адміністративного права України. I другим етапом $\epsilon$ практичне впровадження змін у систему управління 3 визначенням строків, відповідальних виконавців та наслідків невиконання поставлених завдань.

\section{Jimepamypa}

1. Базенко В.А. Європейський досвід управління розвитком фізичної культури та спорту на місцевому рівні. Ефективність державного управління : збірник наук. пр. Львівського регіонального інституту державного управління Національної академії державного управління при Президентові України. Вип. 1 (50) : у 2 ч. / за заг. ред. чл.-кор. НАН України В.С. Загорського, доц. А.В. Ліпенцева. Львів : ЛРІДУ НАДУ, 2017. С. $156-168$

2. Рекомендації парламентських слухань на тему: «Шляхи розвитку фізичної культури і спорту в Україні в умовах децентралізації влади»: Проект Постанови Верховної Ради України від 23.05.2016 p. № 4709. URL: http://w1.c1.rada.gov.ua/pls/zweb2/ webproc4 1?pf3511=59201 (дата звернення 25.10.2018)

3. Калина М.С. Актуальні завдання державної політики України у сфері фізичної культури та спорту в умовах глобалізації та євроінтеграції. Інвестицї: практика та досвід. 2016. № 21. С. 91-95.

4. Про схвалення Концепції Державної цільової соціальної програми розвитку фізичної культури і спорту на період до 2020 року : Розпорядження Кабінету Міністрів України від 09.12.2015 р. № 1320-р. Офіиійний вісник України. 2015. № 102. С. 163. Ст 3529, код акта $79963 / 2015$.

5. Обозна О.М. Розвиток фізичної культури і спорту як важливий напрям державної політики України щодо забезпечення здоров'я громадян. Державне управління: теорія та практика. 2014. № 2. С. 39-44.

6. Ліщук С.В. Система державного регулювання у сфері фізичної культури та спорту в Україні. Державне управління: удосконалення та розвиток. 2014. № 12. URL: http://www.dy.nayka.com.ua/?op=1\&z=794 (дата звернення 25.10.2018)

7. Конституція України: Закон України від 28.06.1996 р. № 254к/96-ВР. Офіційний вісник України. 2010. № 72/1. Спеціальний випуск. С. 15. Ст. 2598.

8. Про затвердження Положення про Міністерство молоді та спорту України : Постанова Кабінету Міністрів України від 02.07.2014 р. № 220. Офіuійний вісник України. 2014. № 54. С. 66. Ст. 1447, код акта $73101 / 2014$.

9. Нікітенко С.В. Особливості нормативно-правового регулювання фізичного виховання і спорту в Україні. Державне управління та місиеве самоврядування. 2016. Вип. 1. С. 95-100.

10. Алікова О.М. Організаційно-правові форми діяльності державних органів у сфері фізичної культури і спорту. Актуальні проблели держави і права : збірник наук. пр. 2005. Вип. 25. С. 210-214.

11. Сімутін В.В. Змістоутворюючі засади організації та діяльності механізму сучасної держави. Науко- вий вісник Міжнародного гуманітарного університету. Серія: «Юриспрудениія» : зб. наук. праць. Одеса : Фенікс, 2013. Вип. № 5. С. 56-9.

12. Базенко В.А Механіз підтримки розвитку фізичної культури та спорту в умовах децентралізації. Молодий вчений. 2017. № 1 (41). С. 172-178.

13. Шкребтій Ю.М. Спортивне законодавство зарубіжних країн і перспективи удосконалення системи фізичної культури і спорту в Україні. Теорія $i$ методика фізичного виховання. 2005. № 1. С. 2-7.

14. Базенко В.А. Розвиток фізичної культури та спорту в умовах децентралізації. Актуальні проблели державного управління : збірник наук. пр. ОРІДУ / голов. ред. М.М. Іжа. Вип. 2 (62). Одеса : ОРІДУ НАДУ, 2015. С. $61-64$.

\section{Анотація}

Моргунов О. А. Фізична культура та спорт як напрям публічного адміністрування в Україні. - Стаття.

У статті визначено напрями дій суб'єктів публічного адміністрування у сферах фізичної культури та спорту в Україні задля вирішення актуальних проблем рівня здоров'я населення, здорового способу життя, залучення до спорту, гідного представлення України в спортивних змаганнях. Визначено, що визначальна роль і позиція центрального органу влади серед суб'єктів публічного адміністрування сфери фізичної культури та спорту в Україні пояснюється історичними передумовами та попереднім розвитком управління в державі загалом, а не тільки цієї сфери. Спадкування системи управління після розпаду СРСР не тільки включає спадковість науки, про яку ми зауважували у попередньому підрозділі, але і спадковість чинної системи управління. Наголошено на залежності об'єктів управління у сферах фізичної культури та спорту від суб'єктів, що особливо проявляється у взаємодії національних спортивних федерації та центрального органу виконавчої влади, який формує та реалізує державну політику у сферах фізичної культури та спорту в Україні. Тим самим порушується рівновага між державною владою та муніципальною владою, між державою і громадянським суспільством у процесі управління сферою фізичної культури та спорту в Україні. Зроблено висновок про двоаспектну концепцію дій суб'єктів публічного адміністрування в рамках реформування сфер фізичної культури та спорту в Україні, що характеризує роль та значення публічного адміністрування в системі управління відповідними сферами. 3 одного боку, необхідними є зміни державної політики у сферах фiзичної культури та спорту у напрямі підвищення рівня обізнаності всіх вікових категорій населення України про важливість занять спортом, сприяння здоровому способу життя, поширеення масового спорту, підвищення результативності професійного спорту, для чого суб'єкти публічного адміністрування мають необхідні ресурси та повноваження. 3 іншого боку, дії суб'єктів публічного адміністрування в рамках реформування сфер фізичної культури та спорту в Україні мають охоплювати зміни відповідної системи управління в аспекті розподілу повноважень між суб'єктами публічного адміністрування, принципів, форм, методів їх діяльності, децентралізації публічного адміністрування.

Ключові слова: публічне адміністрування, управління сферами фізичної культури та спорту, публічне адміністрування спорту, суб'єкти публічного адміністрування, державне управління, місцеве самоврядування. 


\section{Summary}

Morhunov O. A. Physical culture and sports as a field of public administration in Ukraine. - Article.

In the article is defined the directions of actions of subjects of public administration in the areas of physical culture and sports in Ukraine to solve actual problems of the level of health of the population, a healthy lifestyle, involvement in sport, and a decent representation of Ukraine in sports competitions. It is determined that the decisive role and position of the central authority among the subjects of public administration of the sphere of physical culture and sports in Ukraine is explained by the historical prerequisites and the previous development of government in the country as a whole, and not only in this sphere. The inheritance of the system of governance after the collapse of the USSR not only includes the heredity of science, which we noted in the previous section, but also the heredity of the current system of government. The emphasis is on the dependence of the objects of management in the fields of physical culture and sports on the subjects, which is especially manifested in the interaction of national sports federations and the central executive body, which shapes and implements state policy in the fields of physical culture and sports in Ukraine. Thus, the state and municipal authorities, the state and civil socie- ty in the process of managing the sphere of physical culture and sports in Ukraine are disturbed. The conclusion is drawn about the two-dimensional concept of actions of the subjects of public administration in the framework of reforming the spheres of physical culture and sports in Ukraine, which characterizes the role and importance of public administration in the system of management of the respective spheres. On the one hand, it is necessary to change the state policy in the spheres of physical culture and sports in order to raise the level of awareness of all age categories of the population of Ukraine about the importance of sports, promoting a healthy lifestyle, the spread of mass sports, improving the effectiveness of professional sports, for which the subjects of public administrations have the necessary resources and powers. On the other hand, the actions of the public administration entities in the framework of reforming the physical education and sports spheres in Ukraine should cover changes in the relevant management system in terms of the distribution of powers among the public administration entities, principles, forms, methods of their activity, decentralization of public administration.

Key words: public administration, management of physical culture and sports, public administration of sports, subjects of public administration, government, local government. 